\title{
Cripping Criminology
}

Ryan Thorneycroft ${ }^{1}$ and Nicole L Asquith ${ }^{2}$

Abstract

The position of disabled people within criminal justice frameworks and scholarship is one of ambivalence, which leaves disabled people in the simultaneous and contradictory position of centrality and marginality. While disabled people are over-represented within the criminal justice system (as offenders, victims, and witnesses), their voices are often marginalised or silenced. So too, while disabled people are over-represented within the criminal justice system, they remain under-explored in policy, practice, research, and scholarship. Aligning with the shift to queer and queering criminology, in this article we deploy the lens' of 'crip' and 'cripping' to facilitate a more critical engagement with the concerns of disabled people, along with the mechanisms by which abledness informs criminal justice encounters.

Keywords

Ableism, crip, abledness....

1 Dr Ryan Thorneycroft, Lecturer in Criminology, School of Social Sciences \& Psychology, Western Sydney University. Locked Bag 1797, Penrith NSW 2751 Australia. +61 297726988. r.thorneycroft@westernsydney.edu.au

2 Dr Nicole L Asquith, Associate Professor in Policing and Criminal Justice, School of Social Sciences and Psychology, Western Sydney University. 


\section{Cripping Criminology}

\section{Introduction}

The position of disabled people within criminal justice frameworks and scholarship is one of ambivalence, which leaves disabled people in the simultaneous and contradictory position of centrality and marginality (Steele and Thomas, 2014). While disabled people are over-represented within the criminal justice system (as offenders, victims, and witnesses), their voices are often marginalised or silenced. Constituted as unreliable, or positioned as suspicious, their views and experiences are often dismissed and invisibilised. So too, while disabled people are over-represented within the criminal justice system, they remain under-explored in policy, practice, research, and scholarship (Steele and Thomas, 2014). And while disabled people are over-represented as victims, they are also under-represented in their access to justice. Disabled people thus have a contested and complex relationship with the criminal justice system and the field of criminology, and in this article, we seek to explore the nexus between disability and criminology in the pursuit of cripping criminology. We use the terms 'crip' and 'cripping' as a deliberate trope to problematise both the biomedical and social models of disability. In alignment with the shift to queer and queering criminology, in this article we deploy the lens of 'crip' and 'cripping' to facilitate a more critical engagement with the concerns of disabled people, along with the mechanisms by which abledness informs criminal justice encounters.

Disabled people are abjected by the criminal justice system even before they encounter its practices. Ableism and disablism are constitutive elements of many modern societies (Campbell, 2009a), and like other social practices, run in and through the criminal justice system. Just as Sir William Macpherson argued that the police in the UK were 'institutionally racist' (Chakraborti, 2015), it is our claim that the criminal justice system and criminology are institutionally and theoretically ableist. Ableism and disablism are under-explored concepts in the field of criminology. In this article we tease them out to explore the ways in which disabled bodies and lives are constituted, regulated, governed, and violated by criminal justice frameworks. We explore the relationship between crip and criminology in order to articulate sites, practices, and opportunities in which disabled bodies and lives can attain justice within an ableist 
criminological institution. Our exposition is an act of provocation, as we aim to subvert and disrupt criminology from the inside in order to expose its ableism and disablism, and identify the ways in which criminology might be cripped.

In exploring the prospects of a crip criminology we are indebted to the work of feminist, critical race, and queer criminologists who have come before us. In this paper, we focus on the theoretical legacies and links with queer criminology, which itself has been informed by critical studies of masculinity and whiteness. Over the past few years, scholars have established and defended a queer criminology that provides a nourishing resource for (queer) criminological scholarship (see: Ball, 2014, 2016; Ball, Buist, and Woods, 2014; Dalton, 2016; Dwyer, Ball, and Crofts, 2016; McDonald, 2016; Tomsen, 2006, 2009; Woods, 2014). We are guided by their work in taking their insights and identifying the points of intersection, similarity, and departure in formulating this notion of crip criminology. Ahmed (2017: 1516) writes that citation 'is how we acknowledge our debt to those who came before; those who helped us find our way when the way was obscured because we deviated from the paths we were told to follow'. To follow a crip perspective in some senses betrays all that is normative about criminology as a discipline; thus, queer theorists have laid a path that is a little easier for us to follow. As authors, we are appreciative of this field and the ways in which it has enabled us to think of criminology and crip in new and different ways.

In thinking with and through the problem of ableism and disablism in criminology, we are inevitably confronted by the realities of our own dis/abled bodies in relation to the category of 'disabled'. Despite what follows, we are critical of the need to position ourselves in terms of our dis/abled selves. Campbell (2019: 145) suggests that:

'Abled', 'Disabled' is not a thing, a noun or indeed an adjective. To hold this belief is to engage in conflicted proliferating thinking that takes the subjectivity of ' $\mathrm{I}$ ' as its object, starting and return point. To pursue the endless question of who is deemed 'disabled' and 'abled' becomes redundant.

Yet, position ourselves we must, lest those with the power to decide upon labels question our authority to speak on such matters. Ryan is temporarily abled, yet has lived with a disabled sister most of his life. 
Nicole manages a chronic health condition and has been disabled in a variety of contexts over the last 30 years. In advocating a politics that seeks to lay bare and subvert the discursive construction of seemingly stable categories, we are cognisant of the ways in which our own bodies have been dis-abled in temporal and spatial moments. While our lived experiences of disability do not necessarily provide us with the theoretical and analytical skills to engage with abledness, they do offer us a nuanced understanding of the barriers presented by abledness in practice. We use Young's (1990: 152) claim that '[w]omen in sexist society are physically handicapped' to thus broaden what we mean by disablement. Ultimately, the question of whether someone is disabled or not detracts from a more pressing consideration: the ways in which someone's positionality or situated knowledge resonates with dis/abledness (Campbell, 2009b). We also subscribe to Shildrick and Price's (1996: 96) argument that abled and disabled 'are always provisional and insecure categories which can never be entirely separate’.

In the discussion that follows, we introduce the notion of crip (theory) before illuminating the ways in which crip lives have haunted the discipline of criminology from the beginning (Fiddler, 2018; Lombroso, 1911). We then move to consider what the tasks and subjects of a crip criminology might look like, and then conclude with a consideration of where crip criminology might sit within the broad field of criminology. We wonder, speculatively and openly, what this concept of crip criminology might do or mean for disabled bodies and lives.

\section{What is Crip (Theory)?}

Crip is a slippery and elusive concept, and this is the case because of its demand for permanent contingency. Historically used as an invective ('you crip/ple!'), the term crip has come to denote people, groups, attitudes, behaviours, practices, activism, and scholarship. The term can be understood and used as a noun, adjective, verb, or adverb, and this multiplicity exacerbates confusion because each use demands different questions, problematisations, and effects. However, as we will go on to demonstrate, the multiplicity and expansiveness of crip allows for the emergence of possibility rather than foreclosure (McRuer, 2006). As a school of thought, crip theory emerges as a reaction to the normalising effects of disability studies, much in the same way queer theory did with gay and lesbian studies (Sandahl, 2003). 
As such, it is an inherently political field because its starting point is a rejection of crip and disability as synonymous categories.

Disability studies explores the social life of disability, examining how bodies, minds, relationships, communities, and social practices coalesce around disability and disablement (Goodley, 2011). Disability studies has arguably reached a point of 'conceptual exhaustion' (Campbell, 2019: 143), whereby its normalising approach to disablement (Goodley, 2011), and the tiring 'intellectual masturbation' (Oliver, 2009: 50) over the social model $^{3}$ has led to weary arguments and repetitive intellectualising (see: Goodley, 2001; Hughes and Paterson, 1997; Levitt, 2017; Woods, 2017, for examples). In fact, the proliferation of crip theory can be explained as a response to the problems with disability studies (Goodley, 2011). While the starting point of disability studies is that disability is an identity, crip theory largely departs from this claim. Rejecting the notion that disability is an essentialist category, crip theory moves from identity to subjectivity, to examine the ways in which bodies and lives are constituted, regulated, governed, and violated. For crip theorists, a key concern with citing identity discourses is that it further re-instantiates them, thus reinforcing the relations of power and knowledge that have constituted certain identities as less than (Foucault 1978). To be sure, identity categories cannot be abandoned completely in research; despite their constructedness, identity categories can be useful for 'strategic essentialist' ${ }^{\text {'4 }}$ political purposes (Butler, 1993; Spivak, 1990). Suffice to say, crip theorists maintain an approach to (disabled) subjectivity as contingent, permeable, leaky, and revisable (Thorneycroft, forthcoming; Shildrick, 1997).

In part due to essentialist understandings of identity, and the ways in which norms regulate nonnormative subjects, crip theory opposes—indeed seeks to disrupt—normativity. Disability is constituted as a deviation of the norm, and rather than try to normalise disabled lives (as evident in disability studies),

3 Within mainstream criminology, the social model of disability is the most commonly used framework to position disabled people and their experiences. However, since its advent in the 1970s the social model has been attacked in many quarters. Previously seen as a socialised account that examined the ways in which people were dis-abled by social and structural forces, recent post-structuralist work has problematised this approach and unearthed its essentialist character (see: Thorneycroft, forthcoming; Campbell, 2009a; Tremain, 2002). Following Butler (1990, 1993), many now consider the disability/impairment distinction to be as similarly problematic as the sex/gender divide.

$4 \quad$ Strategic essentialism refers to a political tactic whereby members of a particular minority-or an ally of that minority - temporarily essentialise their existence to mobilise change or recognition (Butler, 1993; Spivak, 1990). 
crip theorists try to challenge and subvert normative regimes (Kafer, 2013; McRuer, 2006). The function of disrupting and subverting norms is to open up spaces of possibility in which (crip) lives can be lived.

Ableism and disablism are two inter-related terms that are central to crip theory. Ableism is a:

...system of causal relations about the order of life that produces processes and systems of entitlement and exclusion. This causality fosters conditions of microaggression, internalized ableism and, in their jostling, notions of (un)encumbrance. A system of dividing practices, ableism institutes the reification and classification of populations. Ableist systems involve the differentiation, ranking, negation, notification and prioritization of sentient life (Campbell, 2017: 287-288; emphasis in original).

Ableism is based on the idea that the abled body is natural and normal, and in fact, the 'corporeal standard' and 'species-typical and therefore essential and fully human' (Campbell, 2001: 44). While we live in a world where we can readily identify behaviours such as racism or sexism, ableism is embedded in everyday practice, yet simultaneously invisibilised, unnamed, and unspeakable. It is as if a discourse for ableism does not appear to exist despite its ubiquity. As Butler (1997: 139) writes: '[t]he operation of foreclosure is tacitly referenced in those instances in which we ask: what must remain unspeakable for the contemporary regimes of discourse to continue to exercise power?'. Ableism works to (re)produce the abled body as the norm, and in so doing produces disablism; the belief that disabled people constitute inferior ways of being. Ableism and disablism should not be used interchangeably or conflated, for they 'render quite radically different understandings of the status of disability to the norm' (Campbell, 2009a: 5). Ableism produces ideals surrounding abledness, while disablism produces ideals around disability (Campbell, 2009c). Ableism and disablism are forms of normative violence; the violence of norms and their role in facilitating and occasioning physical violence (Butler, 2004).

Ableism and disablism are important concepts for crip theorists because they provide the platform upon which oppression and abjection is fought. One way of fighting this oppression and abjection is by cripping ableism in a similar way to the queering of heteronormativity (Thorneycroft, 2019). Cripping involves disrupting and subverting abled assumptions, practices, and effects (Sandahl, 2003). 'To crip' involves challenging practices and expectations that the abled body is the normal body, and seeks to 
highlight non-normativity as exposing alternative ways of living and being in the world. Cripping is a political and methodological tool that exposes and critiques oppressive/normative regimes. As with queering criminology, cripping criminology requires scholars to step back from the 'known' and the normative frames of reference that have sustained the discipline from its inception.

\section{The Origins of Crip Criminology-Not all that New}

As Carlen (2017) so rightly points out, despite the normality and ubiquity of crime, critical criminologists are consistently finding an "Other" in criminology and criminal justice practices through which to excavate and interrogate the sacred and founding myths of our discipline. For critical criminologists, it is in the margins and marginal experiences that we find the outliers that unravel long held beliefs about traditional criminological theory. From the standpoint of those who do not fit, conventional theories posited to explain the existence of deviance, the patination of criminal offending and victimisation, and the partial applications of justice, seem not fit-for-purpose. Even within critical criminology, ableism and ableist responses to these conventional problems of criminology remain in spite of their intent. One need only go back to bio-criminology (Lombroso, 1911), or more recently, psychological positivism (Gadd and Jefferson, 2007), or Moffitt's (1993) life-course approaches, to see the ways in which crip has constituted the discipline, unfailingly. Even with a critical mind turned to the power of defining and theorising, ableism is everywhere and nowhere in criminology. It is so normalised in our theoretical work that it is difficult to imagine otherwise, even for critical criminologists. ${ }^{5}$ The tasks of decolonising (Blagg, 2016; Moosavi, 2019; Cunneen \& Tauri, 2016), greening (South, 2017; White, 2016), and queering (Ball, 2016; Buist \& Lenning, 2015) criminology have provided the discipline with alternative frames of reference, and sought to decentre the privileged position of white abled cishet ${ }^{6}$ readings of crime and criminality.

This absent presence (Derrida, 1978, 1997) of disability is not unique to critical criminology; in fact, what little does exist in our disciplinary toolbox and research agendas has come largely from critical

$5 \quad$ Notably, even Carlen and Franca's Alternative Criminologies (2017) failed to include a chapter, along with all the Others, on disability, nor is there a single index reference to disability.

$6 \quad$ Cishet $=$ cis gender, heterosexual. 
criminologists. From criminology's origin myths (as they can no longer be considered theories now that their prejudices and shortfalls have been so thoroughly disputed; we see you, Lombroso) right through to current 'reforms' by criminal (in)justice systems to enable sanctions to become accessible, crip is an absent present. Even the language of deviance and theories of deviancy (Sutherland, 1949; Merton, 1938; Akers, 2017; Hirschi, 1969) bypass the critical interventions made possible when we refigure ableist assumptions about differential associations, social norms, social learning, and internal and external controls, respectively. The autonomous abled subject remains the prototype on which we create theories, propose solutions, and impose regulations.

According to Carlen (2017: 3), alternative criminologies—such as crip criminology—are

...all about Others: those who make the rules... those who break the rules... and all ...those whose rules are so frequently alternatives to others' rules and for whom there is no truth of the matter, no matters of fact and no binding rules for knowing.

If we consider rule-breaking — and its attendant punishments-from the perspective of those who do not know there are rules, let alone the social requirements adhered to following those rules, the implications for criminal (in)justice practices extend beyond the crip offender presented before court. It also redirects our attention away from tinkering with the design of criminal (in)justice processes (and making these more accessibly violent) to the downstream imperatives required to enculturate everyone into civil human relationships. It also brings into stark relief the myriad of ways in which current criminal (in)justice practices are designed to catch out those naïve to its practices—such as verballing and intimidation by police.

Criminological theory, for the most part, has assumed an abled offender, who accepts the interpellating hail from the police officer (which will be inevitably forestalled for a number of crip subjects; Althusser 1970). Criminological thought has also founded its theories on the assumption that those who are interpellated understand that their behaviour is criminal, and that they understand the processes instigated when they act in ways that they do not know are deviant. Too often, disabled offenders-particularly those managing mental health crises-are criminalised because of their 
'abhorrent' behaviour (McCausland \& Baldry 2017). Acting in ways not within the repertoire of abled offenders; acting in ways that seem out of place, or in the wrong place, has led to disabled people's behaviours being initially pathologised, and their grotesque bodies removed to places out-of-sight—the asylum (Foucault 2006; Haney 2017). Now they are removed to alternative out-of-sight places such as the prison (Parsons 2018; Harcourt 2005). Being interpellated into the criminal (in)justice system simply shifts disabled people from a system based nominally on an ethics of care to one of criminalisation and containment; it does little to change the lived experiences of exclusion. The asylum and the prison serve a similar purpose for disabled people, in that both aim to sanitise public space, and rid the abled world of the discomfort and disquiet that adheres to the crip body.

This disciplinary baggage of exclusion is intersectional. Not only does abledness intersect with whiteness and masculinity, it is also heteronormative. While we focus here on the intersections between sexuality and abledness, over the last 15 years, criminology has interrogated the intersectional coordinates of the discipline, particularly in relation to race and gender (Burgess-Proctor, 2006; Henne \& Troshynski 2013; Potter, 2015; Taylor et al, 2010). Tomsen (1997) suggests that there is an embarrassing genealogical origin of criminology through Lombroso's work, where sexual and gender minorities were labelled as insane, degenerate, deviant, and invert through bodily and anatomical examinations. Here we see how sexual and gender minorities — and, for that matter, most minority groups—-were constituted in the first place as disabled, thus highlighting the crip origins of (queer) criminological thought. Baynton (2001) has highlighted how the historical oppression of other abjected groups has been justified by constituting such groups as disabled; thus, disability haunts other fields of study, including criminology where it has been an absent presence (Derrida, 1978, 1997) from the very beginning. The arguments Tomsen raises in relation to sexuality have also discussed by critical race and feminist theorists, who have similarly documented the ways in which the powerless are framed as dis-abled (Young 1990).

It could be suggested that proposing a crip criminology is pre-emptive, in that it has not formerly emerged in any coherent way to warrant an exposition of its key themes, let alone argue for its legitimacy as a particular subfield of criminology. However, we posit that this interpretation is incorrect, given the 
body of research that has already been done in this area (see: Thorneycroft, forthcoming; Baldry, 2014; Dowse, 2017; Dowse, Baldry, and Snoyman, 2009; Harpur and Douglas, 2014; Minkowitz, 2014; Spivakovsky and Seear, 2017; Spivakovsky, 2014; Steele, 2014, 2017; Steele and Thomas, 2014; Thorneycroft and Asquith, 2017; Wadiwel, 2017; Weller, 2014, 2017) ${ }^{7}$. Additionally, it is a timely intervention because criminology has been crip/pled all along. For example, Bone (2017: 1302) suggests that crip does not remind her of dis/ability ${ }^{8}$, but rather takes her back to 'when the Bloods lived on one end of the street and the Crips lived on the other'. Indeed, a sizeable body of literature examines gang culture, warfare, and violence (see: Ferrell, 1995; Panfil, 2017; Sanders, 1994). We suggest that this field of study is also crip (in the disability sense). McRuer (2006: 65) observes that disability 'has haunted Crip reality from the beginning', where gang members are at heightened risk of becoming disabled (through violence). Many gang members have also historically used canes as fashion accessories, thus cripping the ableist physical environment (McRuer, 2006). In any case, gangs might be perceived as on their way to disablement, and consequently, a study of Crips and gangs is a keen (crip) criminological concern. Examples of crip's absent presence is littered throughout criminology; so too is its present absence. Only in the last decade has criminology begun to consider the fact that most victims and offenders processed by criminal justice institutions are or will be constituted by their lack of abledness.

\section{The Need for a Crip Criminology}

For (critical) disability studies scholars, the need for a renewed focus on disabled people and their interactions with the criminal justice system and broader society may seem self-evident. After all, disabled people are generally more likely to experience violence than non-disabled people, and have been pathologically regulated, governed, and institutionalised (Davis, 1997; Sherry, 2010). And yet, the victimisation of disabled people is too often met with bewilderment. Who could possibly do that to disabled people? The reality is that they do, and it happens a lot (Sherry, 2010). Another concern is the over-

\footnotetext{
Albeit we acknowledge this research is not conducted under the name of crip criminology, nevertheless the themes of crip criminology and crip theory run through them.

8 Dis/ability is a split term that denotes the ways in which ability and disability, ableism and disablism, are constituted in simultaneous relation to one another.
} 
representation of disabled people as suspects and offenders, whose experiences of (in)justice is too often reliant upon self-disclosure despite the significant barriers in doing so, including not being aware of their disability, not identifying as having one, never having been diagnosed prior to encountering the criminal justice system, or simply, hesitation in disclosing for fear of further discrimination and stigma (Human Rights Watch 2018).

The Ministry of Justice (2012) in the UK estimates thirty-six percent of their prison population are interpellated as disabled. ${ }^{9}$ More recently, Human Rights Watch (2018: 1) has identified that 'people with disabilities, particularly a cognitive or psychosocial disability, are overrepresented in the criminal justice system in Australia—comprising around 18 percent of the country's population, but almost 50 percent of people entering prison'. One pressing consideration is how an ableist institution is able to attend to the unique needs of heterogeneous disabled subjectivities? Christie's (2000: 183) notion of 'dangerous states' captures both victims' and offenders' experiences with the criminal justice system. Criminal (in)justice is a 'danger that national states represent in their penal law approach towards their own citizens'. In any case, a crip understanding of prison life and broader criminal justice experiences is warranted.

Yet, to date, crip theory—or even critical disability studies, for that matter-have failed to gain purchase, let alone consideration and integration into the core techniques and tools necessary to understand how it is that criminal (in)justice regulates and normalises violence against disabled people. Whether it is the disciplinary theory or the discipline's subjects (including the criminal processing system), and even when they note (on those rare occasions that they do so) that many people subject to the power of criminal processing systems are disabled, the presence of disabled people is quickly absented in favour of ableist interpretations of their manifestation in criminology. The behaviours criminology aims to explain, and criminal (in)justice systems seek to regulate, begin (and for the most part, end) with abled assumptions about what constitutes both our theorising and operationalisation. While the doors on

\footnotetext{
9 Of course, this report does not stipulate when disablement occurred (before, during, or after imprisonment), yet in any case it points to the over-representation of disabled people in prison, and the disabling effects of prison life.
} 
prison cells now may accommodate a wheelchair (Conley, 2019), and court rooms may include (in best cases) a hearing loop ${ }^{10}$, criminologists continue to theorise about crime as if the actions of offenders and victims can be explained through the lens of abledness. Too often we are counselled that lack of knowledge or understanding of the law is not justification or cannot be used as mitigation; yet, shared with their illiterate and innumerate peers, many disabled people cannot know or understand the words in front of them, or the social norms and complex legal concepts underpinning criminal (in)justice processes. The only options for crip people is to trust guardians' knowledge and understanding, and hope that their own lack of knowledge and understanding will be counted and accounted for in adjudicationwhich too often it is not.

Ultimately, a crip criminology may provide an understanding as to the ways in which victimisation has been previously overlooked or ignored because non-normative lives and experiences have been constituted as less than. A crip criminology may provide new ways of understanding disabled people in criminology, ensure that criminology is better attuned to the needs and complexities of disabled people, and work to highlight the ableism operating within the criminal justice system and criminological scholarship. A crip criminology is required because the status quo is insufficient. Inevitably, in determining the need for a particular field of study, one must ask what tasks or questions it will set itself.

\section{The Tasks of a Crip Criminology}

Should a crip criminology devote its focus to the victimisation, offending, and/or broader experiences of crime and justice for disabled subjects? ${ }^{11}$ Should a crip criminology seek to add crip knowledge to criminology? Or, rather, should the purpose be to crip criminology from its ableist ways of thinking? These are difficult questions with no obvious answers, but they are relevant to what the tasks of a crip criminology might look like. Building upon previous crip criminological work and engaging with crip theory and criminology, it is our intention in this section to provide some principles as to the tasks of a

10 For example, the Australian Federal Circuit Court assures users that at least one courtroom has a hearing loop installed, and that arrangements can be made to assist hearing impaired where practicable (Federal Circuit Court of Australia, 2016).

11 This presumes that disabled subjects are the only focus of a crip criminology, but we turn to consider this point soon. 
crip criminology. Following Ahmed (2017: 256), we do not mean principles in the sense of dictating rules of conduct, but 'principles in the original sense: principle as first step, as a commencement, a start of something'. Recognising the expansiveness of crip theory and the heterogeneity of disabled subjectivity, we offer three starting points while realising that multiple approaches are required, and that some may need to be abandoned in favour of new approaches once they have out-lived their value. We also recognise that the principles put forth are not discrete categories, and that they may be embarked upon simultaneously.

One way in which a crip criminology might operate would be the explicit inclusion of crip people into criminological research and scholarship. Thus far, crip people in criminology are simultaneously everywhere and nowhere, over-victimised and under-recognised. Borrowing from Tomsen (2006), the inclusion of crip people into criminology may provide a cripped understanding of crime. Capturing new people and experiences under the remit of criminological research will not only produce new knowledge about their experiences, but may shed new light on the ableism inherent in criminological theories. Such information may twist_ or crip_ our understandings of criminological research, theory, and knowledge. To be sure, it is equally important that this additive approach to criminology does not (re-)instantiate victimisation nor deviancy models_ part of crip theory is about prising open these binaries. Criminology in this vein must be conducted in an ethical way, where research opens up spaces in which the prohibited and the unnameable are permitted to enter that grid of cultural intelligibility (Butler, 1991). As a field, criminology has historically played a role in constituting, regulating, governing, and violating disabled lives; practicing crip criminology may be an ethical endeavour to remediate that injustice. The ableism inherent within criminology also means that the discipline is unable to effectively examine, understand, or respond to the needs of disabled people. To borrow from Garland-Thomson (2001: 593), within criminology, disabled people sit as square pegs in round holes.

Another approach might see an inversion of focus for typical criminological research, leading to a movement from disablist violence to ableism (Campbell, 2009a). Historically, disability, homosexuality, and race have been studied due to their departure from the norm (and in many respects they still are). 
Yet, as social shifts see a deviancy model lose its grip on the field, it is important that the emphasis shifts to investigate ableism, heterosexism, and racism. Rather than see disability as a departure from the norm-especially given that disabled people constitute up to 50 per cent of criminal justice actors incarcerated and are thus the norm in prison populations (Human Rights Watch 2018)—crip criminologists could use ableism as their object of inquiry to investigate why people engage in disablist violence, or why the system created is ableist in practice. Crip criminology could seek to highlight the ways in which ableist subjects are problematic with their messy abjectifying behaviours. Such research might engage in how we deal with the 'psychopathology of the normals'12 (Goodley, 2014: 117). Disability is constituted as provisional and tentative-'always subject to being erased if a solution comes along (cure, correction, elimination)' (Campbell, 2012: 213). Thus, 'stalking ableism' (Campbell, 2012) may cure their fascination with the abled 'norm'.

Most radically, a crip criminology might advocate the cripping of criminology (that is, using crip as a verb). Cripping is a methodological tool that critiques oppressive regimes, practices, and normativities (McRuer, 2006). Sandahl (2003: 37) writes that cripping ‘...spins mainstream representations or practices to reveal able-bodied assumptions and exclusionary effects'. Within the context of crip criminology, this would mean subverting the ableism endemic to criminology, criminological scholarship, and the criminal justice system. The aim is not to dis-able criminology, but to encourage the field to be more open, inclusive, and accommodating to embodied difference. To be sure, cripping criminology means asking uncomfortable questions and pushing against existing criminal justice frameworks. For now, the three following case studies highlight ableist criminology and criminal justice frameworks, which might produce a greater awareness of what a crip criminology might look like.

12 Goodley (2014) uses 'psychopathology' in a playful sense here, ironically highlighting the damaging effects of constituting people in a particular (damaging) way. 


\section{Example One: Jury Service}

In various jurisdictions, including those in Australia and the UK, several laws or discretionary conventions currently exclude disabled people from jury service. ${ }^{13}$ One noteworthy case in Australia concerned Gaye Lyons, who was called for jury service in the state of Queensland in 2012, but was subsequently excluded by the appointed registrar when she requested an Auslan interpreter ${ }^{14}$ (Lyons $v$ Queensland, 2016). Lyons was told by the registrar that the law enabled the exclusion of jury service for any 'person who has a physical or mental disability that makes the person incapable of performing the functions of a juror' (Lyons v Queensland, 2016). As interpreters are not permitted in jury rooms, Lyons was deemed incapable of performing the functions of a juror and consequently excluded. Lyons lodged a formal complaint and the case went to the High Court of Australia where it was dismissed (Lyons v Queensland, 2016), thus upholding the state's ability to discriminate against disabled people and forbid them from jury service even when they have the civil right and cognitive ability to do so.

Disabled people are literally excluded from equal citizenship before the law. If we are to be judged by our peers in court, then surely this must include disabled people given that our peers, as well as the offenders and victims we adjudicate, are as likely to be disabled. A crip criminological perspective would highlight the ableism and disablism existing within this criminal justice framework, and then seek to subvert those ableist and disablist practices from the system. This would mean that disabled people are no longer excluded from jury service. But as we have suggested, in pushing against existing criminal justice frameworks, it is inevitable that uncomfortable questions are raised. While complexities are bound to unfold, cripping this space opens up conversations and considerations that are currently not taking place.

13 This sad reality highlights the current positioning of disability in society today. Imagine, for example, the outcry if women or people of colour were excluded from jury service.

14 Auslan refers to the predominant language used by the deaf community in Australia. 


\section{Example Two: The Multiple Voices of Victimisation}

Central to criminal (in)justice processes is the role of witnesses and victims in accounting for the harms caused by offending. Criminology has been largely fixated on the offender and their motivations, and the integral role of victims-especially in interpersonal violence-has been ignored until recently (Rock, 2010). In disablist violence, as with hate crime, incest, sexual assault, and intimate-partner violence, the victim is critical to our understanding of why some people break social and legal rules (Thorneycroft and Asquith, 2017; Walklate, 2007). Consideration of victims and their needs highlights how the systems developed to respond to rule-breaking are not only ableist for offenders but also victims and witnesses. This is starkest in the ways in which evidence is (ac)counted in legal adjudication, and the veracity of victims' accounts of the violence experienced (Walklate et al., 2018). Across the world, legal systems are increasingly accessibilising their functions to enable all people to be active participants in the justice they seek. The case of Jeni Hayes in New South Wales, Australia, provides us with an example of how accommodating disability can fundamentally transform the theoretical and operational contours of criminal justice and, in turn, criminological theory.

Jeni Haynes was sexually and physically assaulted by her father between the ages of four and 11 . During this time, Jeni manifested 2500 'alters' to cope with the trauma and harm caused by her father during these years of abuse. Diagnosed in the DSM-5 and elsewhere as dissociative identity disorder (and often called multiple personality disorder), people with these manifestations are commonly precluded from criminal justice practices, for the most part, because the evidence they provide is perceived as having no veracity. For a criminal justice system that prides itself on absolute and single notions of truth and justice, the appearance of 'Symphony, a four-year-old girl; an 11-year-old boy named Judas; Muscles, an 18-year-old motorcycle-loving lout; and Linda, who was cheated out of a political career' (Barlass 2019), can well and truly disorient the legal system.

The case of Jeni Haynes, therefore, is ground-breaking. Not only was her evidence prioritised by the presiding judge in sentencing her father, Jeni was provided the space and time to allow 33 of her 'alters' to give evidence of the unique harms caused to each of them. In her 17-page victim impact 
statement, Haynes provided an account of her abuse that relied on stitching together the partial snippets of memory each alter could provide, resulting in an interwoven narrative of abuse. The accommodations provided to Ms Haynes opens the way for trauma-informed justice to become standard in adjudication, and whilst legal commentary on this case is forthcoming, we include this example to illustrate the ways in which central features of criminal justice processes (including memory and witnessing) can be cripped, and in doing so, cripping criminological endeavours.

\section{Example Three: Criminal Responsibility, Insanity, and Unfitness to Plead}

Our third example is provocative, and it involves an inter-related discussion of criminal responsibility, the insanity defence, and unfitness to plead in criminal trials. Conventionally, insanity is used as a mechanism to preclude individuals from trial or prosecution, stemming from the presumption that a person must have the requisite cognitive ability and rational capacity (Weller, 2014). People constituted as insane are stigmatised and often incarcerated indefinitely (Minkowitz, 2014). These approaches are discriminatory towards disabled people, and a crip criminology might advocate for the abolition of insanity defences. Rationality should not 'be the talisman of our social or legal norms and relations' (Minkowitz, 2014: 437), and we should not set people aside for their non-normative perceptions and/or beliefs. Our approach might seem radical and impractical, yet Slobogin (2000) already highlights how the criminal justice system can attend to disabled people without insanity defences. Defences of justification, excuse, and failure of proof (the absence of mens rea, for example) all provide scope for people without the need for insanity defences (Slobogin, 2000). Not only are insanity defences 'in a state of [legal] chaos' (Slobogin, 2000: 1199), they constitute groups of people in a pathological manner. The purpose of a crip criminology is to prise open the ways in which these people are constituted, and then imagine a different future.

A crip criminology, then, is multiplicitous and radical in its focus and politics. The focus of crip criminology may be expansive or limited, yet nevertheless working to expose and disrupt the ableist and disablist practices working within, beyond, beneath, and beside criminological practice and research. One 
other consideration, though, is the question of whom (or what) does a crip criminology speaks of, for, to, or about?

\section{The Subjects of a Crip Criminology}

A crip criminology must speak of, for, to, and about particular subjects. This is not new territory; women, people of colour, and queers have already attempted to shift the subjects of criminology to account for those left off the agenda of our discipline (Smart 1976; 1990; Ball 2016; Smith 2014). This activism has facilitated a partial inclusion of others in our disciplinary lens, insofar as it has begun to account for the "problems" of others. Yet, as with adding crip to the mix, simple inclusion may not result in disciplinary shifts, especially when the first actor in dualisms are ignored in favour of problematizing the second actor (e.g. man/woman; cisgender/transgender; white/black etc) (Smith, 2014). But before we can begin to account for abledness, we require a deliberate and organised process of seeking out the voices of crips. As with others who have sought to expand the horizons of criminology, however, too often, an "add and stir" approach is assumed sufficient even though it fails to address the power invested in those who get to decide if we are to be included at all (Lavis \& Walker, 2013; Chesney-Lind \& Chagnon, 2016; Smith 2014).

As such, this is a more serious endeavour than researchers might otherwise think, because in speaking of, for, to, or about others they are 'participating in the construction of their subject-positions' (Alcoff, 1991: 9)—positions that may ultimately be oppressive or constitute people in a particular (pathological) way. In proposing a crip criminology it may seem logical that crip subjects will be the object of inquiry (crip here being read as disabled people). It is important that such work continues in understanding the ways in which crip subjects are (re)constituted, regulated, and violated by criminal justice frameworks. Foregrounding crip voices and experiences is only one component of cripping criminology. In line with similar arguments made by feminist, queer and critical race theorists, we suggest this field is much wider, and includes:

1. Disabled people who (are more likely to) commit crimes or are victimised;

2. People disabled as a consequence of criminal behaviour or victimisation; 
3. People iatrogenically harmed by the criminal justice system (such as the onset or exacerbation of mental health disablement arising from imprisonment and victims' participation in criminal (in)justice processes);

4. Ableist criminal justice systems;

5. Ableist criminological theory.

In advocating that the subjects of a crip criminology should remain open and contested, we turn our attention to the abled subject. In addition to considering the crip subject, we suggest it is also important for crip criminology to broaden its focus to abled people, and thus open up new dialogues, questions, and possibilities. A crip criminology might also look at the abled subject and their ableism. It is typically the case that the first half of most binaries remain unexplored and uninterrogated, left constituted as some natural essence (for example, man/woman, white/black, abled/disabled). While a crip criminology should work to deconstruct this binary, it must also divert its attention to the abled subject and the ableism they (may) (re)produce. Just as crip criminology can illuminate the ways in which crip subjects have been constituted and regulated by the criminal justice framework and broader society, so too can these theories communicate this to the abled subject. Ableism is not only oppressive to disabled peopleit is oppressive to everyone. Ableism instantiates social scripts on all people's lives, relationships, productivity, and ways of being in the world. Crip theory may prove liberating for the privileged and productive abled subject, given there is enormous labour involved in performing abledness, and too often abled people are just temporarily so.

\section{Situating Crip Criminology within the Discipline}

A crip criminology of the type we have described requires it to be situated within a particular field or subdiscipline. One consideration is whether criminology could ever be 'home' to crip people. To date, criminology has not invited crip people, scholars, and activists to be part of its endeavours, let alone invited it into its home (one need only look at the absence of crip issues in leading criminological journals). Some have tied crip criminological issues to critical criminology (see Ben-Moshe, 2018, and the Griffith Law Review's 2014 special issue 'Disability at the Peripheries'), while others have avoided the 
criminological canon completely and pursued social science journals, including Disability \& Society and Continum: Journal of Media \& Cultural Studies. It may make sense for crip criminology to be situated within critical criminology given its focus on crimes of the powerful and concern for structures of power that constitute people in particular ways. Cultural criminology may make an appropriate home, too, for its focus on the ways in which crime is constituted and re-constituted through social and cultural dynamics, and its emphasis on emotion and experience in the context of social and structural changes in wider society. Equally, with the turn to harm, crip criminology may be better placed as crip zemiology given this disciplinary lens' ability to consider the harms (personal and iatrogenic) linked to subjectivities and practices.

Nevertheless, our submission to Theoretical Criminology is part of a performative politics that seeks to orient crip criminology towards a mainstream approach, yet simultaneously crips criminology in the process. The exclusion of crip from mainstream discussion says something about the social state of disability — it is an abject state that is only made intelligible on the margins (Thorneycroft, forthcoming). It may be difficult to situate crip within a mainstream criminology that it is not part of, yet crip's utility as an expansive position and subversive function is promissory. We also recognise the contested and contradictory relationship between crip and criminology; after all, the former is deconstructive yet the latter is an archaic term imprisoned within a discipline. As Smart (1990: 77) once said,

[t] he thing that criminology cannot do is deconstruct crime. It cannot locate rape or child sexual abuse in the domain of sexuality or theft in the domain of economic activity or drug use in the domain of health. To do so would be to abandon criminology to sociology; but more importantly it would involve abandoning the idea of a unified problem which requires a unified response - at least, at a theoretical level.

Like South (1997), we are sceptical of this (reductionist) claim, and we approach criminology as a broad and multiplicitous domain; one that is capable of embracing and working with multiple positions and stances (including crip). Ultimately, Smart (1990) can only 'deconstruct' criminology once she has homogenized it and invisibilised its inherent sociological expression (South, 1997). 
Guided by Ball's (2016) work with queer criminology, we take a stance of crip and criminology as 'dangerous bedfellows'. Building on Foucault's (1997: 256) observation that 'everything is dangerous', Ball (2016) pursues an approach that is cognisant that bringing together queer theory and criminology is a dangerous process. Just as with queers, criminology and criminal justice practices have been dangerous to crip subjects; its purpose and goals are antithetical to the lived experiences and needs of crip subjects. The purpose and use of queer in queer criminology is to

be recalcitrant, acting as a continual disruption and a constant danger, thwarting criminology's attempts to capture it and put it to work for ends that it does not agree with, that it was not designed for, or that it does not understand (Ball, 2016: 15).

Similarly, crip should be conceptualised as a disruptive tool within criminology, 'challenging, subverting, and redirecting its major tasks and assumptions' (Ball, 2016: 245). After all, crip would not be crip if it did not have this unwieldy and critical edge.

\section{Conclusion}

The intersections between crip and criminology highlighted in this article expose the ways in which crip criminology can become a productive lens to see the world, and a tool to manifest change. Crip can be used within criminology to the advantage of crip theorists and (crip) criminologists. Importantly, in conceptualising crip criminology in broad terms, its scope can be used at various levels of inquiry and interrogation. One pursuit of crip criminology may merely seek to explore the victimisation effects of disabled people, yet another study may seek to crip the ableism endemic to criminal justice practices. Crip criminology, then, sits on multiple scales, sites, and perspectives. Crip can be used as an intellectual tool that enables researchers to reconsider dominant narratives about disability and criminology that pervade the field. But is criminology ready for crip? 


\section{References}

Lyons v Queensland, 2016, High Court of Australia, 5 October.

R V Brown, 1993, House of Lords, 11 March.

Ahmed S (2017) Living a Feminist Life. Durham and London: Duke University Press.

Akers R (2017) Social Learning and Social Structure: A General Theory of Crime and Deviance. New York: Routledge.

Alcoff L (1991) The Problem of Speaking for Others. Cultural Critique 20: 5-32.

Althusser L (1970) Ideology and Ideological State Apparatus (Notes Towards an Investigation). In: Althusser L (ed.) Lenin and Philosophy and other Essays. London: Monthly Review Press.

Baldry E (2014) Disability at the Margins: Limits of the Law. Griffith Law Review 23(3): 370-388.

Ball M (2014) Queer Criminology, Critique, and the 'Art of Not Being Governed'. Critical Criminology 22(1): 21-34.

Ball M (2016) Criminology and Queer Theory: Dangerous Bedfellows? London: Palgrave Macmillan.

Ball M, Buist CL, and Woods JB (2014) Introduction to the Special Issue on Queer/ing Criminology: New Directions and Frameworks. Critical Criminology 22(1): 1-4.

Barlass T (2019) Jeni and Her Multiple Personalities Have Their Day in Court. The Sydney Morning Herald. Baynton DC (2001) Disability and the Justification of Inequality in American History. In: Longmore PK and Umansky L (eds.) The New Disability History: American Perspectives. New York and London: New York University Press.

Bell DJ (1994) In Bed with the State: Political Geography and Sexual Politics. Geoforum 25(4): 445-452.

Ben-Moshe L (2018) Dis-epistemologies of Abolition. Critical Criminology 26(3): 341-355.

Blagg H (2016) Crime, Aboriginality and the Decolonisation of Justice. Melbourne: Federation Press.

Bone K (2017) Trapped Behind the Glass: Crip Theory and Disability Identity. Disability \& Society 32(9): $1297-1314$.

Buist C \& Lenning E (2015) Queer Criminology. London: Routledge. 
Burgess-Proctor, A (2006) Intersections of Race, Class, Gender, and Crime: Future Directions for Feminist Criminology, Feminist Criminology, 1(1): 27-47.

Butler J (1990) Gender Trouble: Feminism and the Subversion of Identity. New York and London: Routledge.

Butler J (1991) Imitation and Gender Insubordination. In: Fuss D (ed.) Inside/Out: Lesbian Theories, Gay Theories. New York and London: Routledge.

Butler J (1993) Bodies that Matter: On the Discursive Limits of 'Sex'. New York and London: Routledge.

Butler J (1997) Excitable Speech: A Politics of the Performative. New York and London: Routledge.

Butler J (2004) Precarious Life: The Powers of Mourning and Violence. London and New York: Verso.

Campbell FAK (2001) Inciting Legal Fictions: 'Disability's' Date with Ontology and the Ableist Body of the Law. Griffith Law Review 10(1): 42-62.

Campbell FK (2009a) Contours of Ableism: The Production of Disability and Abledness. London and New York: Palgrave Macmillan.

Campbell FAK (2009b) Having a Career in Disability Studies Without Even Becoming Disabled! The Strains of the Disabled Teaching Body. International Journal of Inclusive Education 13(7): 713-725.

Campbell FK (2009c) Disability Harms: Exploring Internalized Ableism. In: Marshall CA, Kendall E, Banks ME, and Gover RMS (eds.) Disabilities: Insights from Across Fields and Around the World, Volume 1, The Experience: Definitions, Causes, and Consequences. Westport: Praeger Publishers.

Campbell FK (2012) Stalking Ableism: Using Disability to Expose 'Abled' Narcissism. In: Goodley D, Hughes B, and Davis L (eds.) Disability and Social Theory: New Developments and Directions. Basingstoke: Palgrave Macmillan.

Campbell FK (2017) Queer Anti-sociality and Disability Unbecoming: An Ableist Relations Project? In: Sircar O and Jain D (eds.) New Intimacies, Old Desires: Law, Culture and Queer Politics in Neoliberal Times. New Delhi: Zubaan.

Campbell FK (2019) Precision Ableism: A Studies in Ableism Approach to Developing Histories of Disability and Abledment. Rethinking History: The Journal of Theory and Practice 23(2): 138-156.

Carlen P (2017) Alternative Criminologies: An Introduction. In: Carlen P \& França LA (eds.) Alternative Criminologies. London: Routledge.

Chakraborti N (2015) Framing the Boundaries of Hate Crime. In: Hall N, Corb A, Giannasi P, and Grieve JGD (eds.) The Routledge International Handbook on Hate Crime. London and New York: Routledge. 
Christie N (2000) Dangerous States. In: Brown M and Pratt J (eds.) Dangerous Offenders: Punishment \& Social Order. London \& New York: Routledge.

Cunneen C \& Tauri J (2016) Indigenous Criminology. Bristol: Policy Press.

Dalton D (2016) Reflections on the Emergence, Efficacy, and Value of Queer Criminology. In: Dwyer A, Ball M, and Crofts T (eds.) Queering Criminology. New York: Palgrave Macmillan.

Davis LJ (1997) Introduction. In: Davis LJ (ed.) The Disability Studies Reader. New York and London: Routledge.

Derrida J (1978) Writing and Difference. Translated by Alan Bass, Chicago: The University of Chicago Press. Derrida J (1997) Of Grammatology. Translated by Gayatri Chakravorty Spivak, Baltimore: John Hopkins University Press.

Dowse L (2017) Disruptive, Dangerous and Disturbing: The 'Challenge' of Behaviour in the Construction of Normalcy and Vulnerability. Continuum: Journal of Media \& Cultural Studies 31(3): 447-457.

Dowse L, Baldry E, and Snoyman P (2009) Disabling Criminology: Conceptualising the Intersections of Critical Disability Studies and Critical Criminology for People with Mental Health and Cognitive Disabilities in the Criminal Justice System. Australian Journal of Human Rights 15(1): 29-46.

Dwyer A, Ball M, and Crofts T (eds) (2016) Queering Criminology. London: Palgrave Macmillan.

Federal Circuit Court of Australia (2016) Hearing and Speech Impaired Clients. Accessed 12 July 2019 $<$ http://www.federalcircuitcourt.gov.au/wps/wcm/connect/fccweb/family-lawmatters/getting-help/disabilities/hearing-speech-impaired-clients>.

Ferrell J (1995) Culture, Crime, and Cultural Criminology. Journal of Criminal Justice and Popular Culture 3(2): $25-42$.

Fiddler M (2018) Ghosts of Other Stories: A Synthesis of Hauntology, Crime and Space. Crime, Media, Culture DOI: 10.1177/1741659018788399.

Foucault M (1978) The History of Sexuality, Vol. I: An Introduction. Translated by Robert Hurley, New York: Pantheon Books.

Foucault M (1997) On the Genealogy of Ethics: An Overview of Work in Progress. In: Rabinow P (ed.) Ethics: Subjectivity and Truth. The Essential Works of Michel Foucault 1954-1984, Volume 1. New York: The New Press. 
Foucault M (2006) History of Madness. Translated by Jonathan Murphy and Jean Khalfa, London and New York: Routledge.

Gadd D and Jefferson T (2007) Psychosocial Criminology. London: SAGE.

Garland-Thomson R (2001) Misfits: A Feminist Materialist Disability Concept. Hypatia: A Journal of Feminist Philosophy 26(3): 591-609.

Goodley D (2001) 'Learning Difficulties', The Social Model of Disability and Impairment: Challenging Epistemologies. Disability \& Society 16(2): 207-231.

Goodley D (2011) Disability Studies: An Interdisciplinary Introduction. London: SAGE.

Goodley D (2014) Dis/ability Studies: Theorising Disablism and Ableism. London and New York: Routledge.

Haney C (2017) 'Madness' and Penal Confinement: Some Observations on Mental Illness and Prison Pain. Punishment \& Society 19(3): 310-326.

Harcourt BE (2005) From the Asylum to the Prison: Rethinking the Incarceration Revolution. Texas Law Review 84(7): 1751-1786.

Harpur P and Douglas H (2014) Disability and Domestic Violence: Protecting Survivors' Human Rights. Griffith Law Review 23(3): 405-433.

Henne, K and Troshynski, E (2013) Mapping the margins of intersectionality: Criminological possibilities in a transnational world, Theoretical Criminology, 17(4): 455-473.

Hirschi T (1969) Causes of Delinquency. Berkeley: University of California Press.

Hughes B and Paterson K (1997) The Social Model of Disability and the Disappearing Body: Towards a Sociology of Impairment. Disability \& Society 12(3): 325-340.

Hughes M, Bain SA, Gilchrist E, and Boyle J (2013) Does Providing a Written Version of the Police Caution Improve Comprehension? Psychology, Crime and Law 19(7): 549-564.

Human Rights Watch (2018) I Needed Help, Instead I W as Punished': Abuse and Neglect of Prisoners with Disabilities in Australia. US: Human Rights Watch.

Kafer A (2013) Feminist, Queer, Crip. Bloomington: Indiana University Press.

Lavis VJ and Walker T (2013) A Contemporary Reflection on Feminist Criminology: Whose side are we on? In: Cowburn M, Duggan M, Robinson A et al (eds.) Values in Criminology and Criminal Justice. Bristol, UK: Policy Press. 57-76. 
Levitt JM (2017) Exploring How the Social Model of Disability Can Be Re-Invigorated: In Response to Mike Oliver. Disability \& Society 32(4): 589-594.

Lombroso C (1911) Crime: Its Causes and Remedies. Boston: Little, Brown.

McCausland R and Baldry E (2017) 'I Feel Like I Failed Him by Ringing the Police': Criminalising Disability in Australia. Punishment \& Society 19(3): 290-309.

Chesney-Lind, M \& Chagnon, N (2016) Criminology, Gender, and Race: A Case Study of Privilege in the Academy, Feminist Criminology, 11(4): 311-333

McDonald D (2016) Who is the Subject of Queer Criminology? Unravelling the Category of the Paedophile. In: Dwyer A, Ball M, and Crofts T (eds.) Queering Criminology. London: Palgrave Macmillan.

McRuer R (2006) Crip Theory: Cultural Signs of Queerness and Disability. New York and London: New York University Press.

Merton RK (1938) Social Structure and Anomie. American Sociological Review 3(5): 672-682.

Minkowitz T (2014) Rethinking Criminal Responsibility from a Critical Disability Perspective: The Abolition of Insanity/Incapacity Acquittals and Unfitness to Plead, and Beyond. Griffith Law Review 23(3): 434-466.

Ministry of Justice UK (2012) Estimating the Prevalence of Disability amongst Prisoners: Results from the Surveying Prisoner Crime Reduction (SPCR) Survey, Available at: https://assets.publishing.service.gov.uk/government/uploads/system/uploads/attachment_data / file/278827/estimating-prevalence-disability-amongst-prisoners.pdf (accessed 21 February 2019).

Moffitt TE (1993) Adolescence-Limited and Life-Course-Persistent Antisocial Behavior: A Developmental Taxonomy. Psychological Review 100(4): 674-701.

Mossavi L (2019) Decolonising Criminology: Syed Hussein Alatas on Crimes of the Powerful. Critical Criminology 27(2): 229-242.

Nussbaum M (2009) The Capabilities of People with Cognitive Disabilities. Metaphilosophy 40(3-4): 331351.

Oliver M (2009) Understanding Disability: From Theory to Practice. 2nd edition. Basingstoke: Palgrave Macmillan. 
Panfil VR (2017) The Gang's All Queer: The Lives of Gay Gang Members. New York: New York University Press.

Parsons AE (2018) From Asylum to Prison: Deinstitutionalization and the Rise of Mass Incarceration after 1945. Chapel Hill, NC: University of North Carolina Press.

Potter, H (2013) Intersectional Criminology: Interrogating Identity and Power in Criminological Research and Theory, Critical Criminology, 21(3): 305-318.

Ricciardi L and Demos M (2015) Making a Murderer. New York: Synthesis Films.

Rock P (2010) Approaches to Victims and Victimisation. In: McLaughlin E and Newburn T (eds.) The SAGE Handbook of Criminological Theory. London: SAGE Publications.

Sandahl C (2003) Queering the Crip or Cripping the Queer? Intersections of Queer and Crip identities in Solo Autobiographical Performance. GLQ: A Journal of Lesbian and Gay Studies 9(1-2): 25-56.

Sanders WB (1994) Gangbangs and Drive-Bys: Grounded Culture and Juvenile Gang Violence. New York: Routledge.

Sherry M (2010) Disability Hate Crimes: Does Anyone Really Hate Disabled People? Farnham: Ashgate Publishing.

Shildrick M (1997) Leaky Bodies and Boundaries: Feminism, Postmodernism and (Bio)ethics. London and New York: Routledge.

Shildrick M and Price J (1996) Breaking the Boundaries of the Broken Body. Body \& Society 2(4): 93-113.

Slobogin C (2000) An End to Insanity: Recasting the Role of Mental Disability in Criminal Cases. Virginia Law Review 86(6): 1199-1247.

Smart, C (1976) Women, Crime and Criminology: A Feminist Critique. London: Routledge \& Kegan Paul.

Smart C (1990) Feminist Approaches to Criminology or Postmodern Woman Meets Atavistic Man. In: Gelsthorpe L and Morris A (eds.) Feminist Perspectives in Criminology. Milton Keynes and Philadelphia: Open University Press.

Smith, JM (2014) Interrogating Whiteness Within Criminology, Crime \& Deviance, 8(2), 107-118.

Snook B, Luther K, Eastwood J, Collins R and Evans S (2016) Advancing Legal Literacy: The Effect of Listenability on the Comprehension of Interrogation Rights. Legal and Criminological Psychology 21(1): 174-188.

South N (ed.) (2017) Green Criminology. London: Routledge. 
South N (1997) Late-Modern Criminology: 'Late' as in 'Dead' or 'Modern' as in 'New'? In: Owen D (ed.) Sociology after Postmodernism. London: SAGE Publications.

Spivak GC (1990) The Post-Colonial Critic: Interviews, Strategies, Dialogues. New York and London: Routledge. Spivakovsky C (2014) Making Risk and Dangerousness Intelligible in Intellectual Disability. Griffith Law Review 23(3): 389-404.

Spivakovsky C and Seear K (2017) Making the Abject: Problem-Solving Courts, Addiction, Mental Illness and Impairment. Continuum: Journal of Media \& Cultural Studies 31(3): 458-469.

Steele L (2014) Disability, Abnormality and Criminal law: Sterilisation as Lawful and 'Good' Violence. Griffith Law Review 23(3): 467-497.

Steele L (2017) Policing Normalcy: Sexual Violence against Women Offenders with Disability. Continuum: Journal of Media \& Cultural Studies 31(3): 422-435.

Steele L and Thomas S (2014) Disability at the Periphery: Legal Theory, Disability and Criminal Law. Griffith Law Review 23(3): 357-369.

Sutherland E (1949) White Collar Crime: The Uncut Version. London: Yale University Press.

Taylor, Y, Hines, S and Casey, M (eds) (2010) Theorizing Intersectionality and Sexuality. Basingstoke \& New York: Palgrave Macmillan.

Thompson B (1994) Sadomasochism: Painful Perversion or Pleasurable Play? London: Cassell.

Thorneycroft R (forthcoming) Reimagining Disablist and Ableist Violence as Abjection. Routledge.

Thorneycroft R (2019) Walking to the Train Station with Amal: Dis/ability and In/visibility. Disability \& Society DOI: 10.1080/09687599.2019.1650720.

Thorneycroft R and Asquith NL (2017) 'Figurehead' Hate Crime Cases: Developing a Framework for Understanding the 'Problem' with Disability. Continuum: Journal of Media \& Cultural Studies 31(3): 482-494.

Tomsen S (1997) Was Lombroso a Queer? Criminology, Criminal Justice and the Heterosexual Imaginary. In: Mason G and Tomsen S (eds.) Homophobic Violence. Sydney: Hawkins Press.

Tomsen S (2006) Homophobic Violence, Cultural Essentialism and Shifting Sexual identities. Social \& Legal Studies 15(3): 389-407.

Tomsen S (2009) Violence, Prejudice and Sexuality. New York \& London: Routledge. 
Tremain S (2002) On the Subject of Impairment. In: Corker M and Shakespeare T (eds.) Disability/Postmodernity: Embodying Disability Theory. London and New York: Continuum.

Wadiwel D (2017) Disability and Torture: Exception, Epistemology and 'Black Sites'. Continuum: Journal of Media \& Cultural Studies 31(3): 388-399.

Walklate S (2007) Imagining the Victim of Crime. New York: Open University Press.

Walklate S, Maher J, McCulloch J, Fitz-Gibbon K, and Beavis K (2018) Victim Stories and Victim Policy: Is There a Case for a Narrative Victimology? Crime, Media, Culture DOI: $10.1177 / 1741659018760105$.

Weller P (2014) Reconsidering Legal Capacity: Radical Critiques, Governmentality and Dividing Practice. Griffith Law Review 23(3): 498-518.

Weller P (2017) Mental Capacity and States of Exception: Revisiting Disability Law with Giorgio Agamben. Continuum: Journal of Media \& Cultural Studies 31(3): 400-410.

White C (2006) The Spanner Trials and the Changing Law on Sadomasochism in the UK. Journal of Homosexuality 50(2-3): 167-187.

White R (2016) The Foundations of Eco-Global Criminology. In: Sollund R (ed.) Eco-Global Crimes: Contemporary Problems and Future Challenges. London: Routledge.

Woods JB (2014) Queer Contestations and the Future of a Critical 'Queer' Criminology. Critical Criminology 22(1): 5-19.

Woods R (2017) Exploring How the Social Model of Disability Can Be Re-Invigorated for Autism: In Response to Jonathan Levitt. Disability \& Society 32(7): 1090-1095.

Young IM (1990) Throwing Like a Girl: A Phenomenology of Feminine Body Comportment Motility and Spatiality. Human Studies 3(1): 137-156. 